\title{
Türkiye'de Göçle Oluşmuş Yaşama Bölgelerine Yönelik Yasal Müdahaleler ve Kentsel Dönüşüm Uygulamaları
}

\author{
Legal Interventions and Urban Transformation Practices \\ for Areas Formed by Emigrations in Turkey
}

\author{
(D) Senem Tezcan, ${ }^{1}$ (1) Hayat Zengin Çelik ${ }^{2}$ \\ ${ }^{1}$ Dokuz Eylül Üniversitesi, Fen Bilimleri Enstitüsü, İzmir \\ ${ }^{2}$ Dokuz Eylül Üniversitesi, Mimarlık Fakültesi, Şehir ve Bölge Planlama Bölümü, İzmir
}

\section{ÖZ}

Ülkemizde yaklaşık 70 yıllık bir zaman diliminde kırdan kentlere yönelen göçler ve fiziksel yansıması olan gecekondular pek çok kentsel müdahalenin konusunu oluşturmuşlardır. Gecekonduların kentsel müdahalelere konu alınmasındaki temel unsur ise, arazi ve yapılaşma ile ilgili konularda sahip oldukları yasal olmayan içerik olmuştur. Bu durum müdahaleleri yönlendiren yasalar için gerekçe yaratmakla birlikte, gecekonduların yayılımı engellenememiş ve popülist tutum ve yaklaşımlar nedeniyle bu oluşumlar Türkiye kentleşme pratiğinin temel dinamiği olarak varlıklarını sürdürmüşlerdir. Bir kısmı yerleşimlerdeki gecekonduları yıkmaya yönelik, bir kısmı yenilerinin yapılmasını önleyici nitelikte olan söz konusu yasal düzenlemeler, barınma hakkını kentte kendine özgü çözüm yöntemleri ile elde eden göçmenlerin giderek mülkiyet hakkına sahip olması için bir meşrulaştırıcı içerik yaratmıştır. Böyle bir gelişme planlama ve yeni imar hakları için de meşru bir zemin yaratırken, kentlerin fiziksel yapılanmasında önemli dönüşümler açığa çıkarmıştır. 2000'li yıllar sonrasında ise bu dönüşüm güçlü bir yasal arka plan ile ve büyük ölçekli projeleri içeren kentsel dönüşüm uygulamaları aracılığıyla farklı bir boyut kazanmıştır. Bu sürecin iki önemli yasal düzenlemesi 5393 sayılı Belediye Kanunun 73. Maddesi ve 6306 sayılı Afet Riski Altındaki Alanların Dönüştürülmesi Hakkında Kanundur ve her iki düzenleme aracılığıla ülke genelinde izlenen bir yeni kentsel deneyim açığa çıkmıştır. Çalışma bu yaygın deneyimi ortaya koymak üzere, Türkiye'deki kentsel dönüşüm uygulamalarını Resmi Gazete ilanları üzerinden ele almakta; projelerin yıllara göre değişimini, mekânsal büyüklüklerini ve uygulamaların ülke genelindeki yaygınlık düzeyini haritalar aracılığıyla göstermeye çalışmaktadır.

Anahtar sözcükler: Kentsel dönüşüm projeleri; Türkiye; 5393 sayılı Belediye Kanunun 73. Maddesi; 6306 sayılı Afet Riski Altındaki Alanların Dönüştürülmesi Hakkında Kanun.

\begin{abstract}
Migrations from rural to cities and slums/slum areas as the reflection of migration have been subject to many urban intervetions in a period of aproximately 70 years in our country Slums subjected as main element of the urban intervetions because of their illegal content on land and houing issues. While this situation creates grounds for legal directing interventions, spread of slums has not prevented, due to populist attitudes and approaches existence of this formations maintained as the fundamental dynamics of urbanization practices of Turkey. Aformentioned legal regulations, some part in demolishing of slums in settlement areas and some part for preventing new slums, created a legitimizing content for immigrants who obtain housing rights with their own unique solution methods in the city. While such a progress created a legitimate ground for planning and new development rights, it has revealed significant transformations in projects. After 2000 s, this transformation acquired dimension with a strong legal background and large scale urban transformation projects. Two important legal regulations of this process are Article 73 of Municipal Law no 5393 and law no 6306 Regarding the Transformation of Areas Under the Risk of Disaster. Through both regulations, a new urban experience has gotten out across the country. This study tries to reveal this common experience, the implementation of urban transformation projects in Turkey through Turkey-Legal Gazette with discusses change of projects by years and their spatial size and tries to show the prevalence of the applications across the country through maps.
\end{abstract}

Keywords: Urban transformation projects; Turkey; law no 6306 Regarding the Transformation of Areas Under the Risk of Disaster; Article 73 of Municipal Law no 5393.

Bu çalışma Dokuz Eylül Üniversitesi Fen Bilimleri Enstitüsünde üretilen "Göçle Oluşmuş Yaşama Bölgelerine Yönelik Dönüşüm Projelerinde Müzakereler" başlıklı tezin bir bölümünden üretilmiştir.

Geliş tarihi: 13.09.2019 Kabul tarihi: 24.07.2020

Online yayımlanma tarihi: I6.10.2020

Iletişis: Senem Tezcan

e-posta: senemtzcn@gmail.com
TMMOB

Şehir Plancıları Odası 


\section{Giriş}

2000'li yıllardan sonra sıklıkla gündeme gelmesine rağmen kentsel dönüşümün temelinde yer alan gecekondu alanlarına ilişkin yasal düzenlemeler göç ve gecekondulaşma süreciyle paralel bir biçimde sürekli olarak yenilenmiştir. Sağlıklaştırma, mülkiyet hakkı tanıma ya da yıkma gibi farklı müdahaleleri içeren ve kısmen parçacıl çözümler sunan düzenlemeler, 1948 yılından günümüze kadar farklı yasalarda yer almıştır. Bu yasalar ile birlikte başlangıçta sadece barınma amacıyla ortaya çıkmış ve giderek biçim değiştirmiş gecekondulara yönelik mevzuat, "kesin" ve "yasaklayıcı" bir dil geliştirmekle birlikte günümüz son yasal uygulamalarına kadar daha çok gecekondu yapımını yasanın çıktığı o tarihe kadar kabul edip, sonrakilerin yıkılacağını dile getirmiş ve aslında tüm süreçte gecekonduları giderek yasallaştırmıştır. 1980'ler söz konusu yasallaştırma işlemlerini af yasaları ile daha açık hale getirirken, giderek üretim mekânlarından tüketim mekânlarına dönüşmeye başlayan kentlerde yeni aktörler ve söylemler eşliğinde büyük ölçekli projelere doğru bir geçiş de yapılmıştır. Bu gelişmeleri son on yıllık süreçte karşımıza gelen iki önemli yasa da desteklemiştir. Kentsel dönüşüm olarak tanımlanan uygulamalar için gerekli meşru zemini yaratan yasalar yoluyla ülke çapında ve hemen hemen bütün illerde merkezi bir biçimde proje alanları ilan edilmiştir. Bu durum tarihsel olarak birbirinin üzerine inşa edilmiş bir mevzuat gelişimi yoluyla ülke genelinde yaratılan etkinin ölçeğini göstermesi açısından önemlidir.

Çalışmada amaçlanan 2000 sonrası mekânsal değişimlerde önemli müdahale aracı olan iki yasal uygulamanın etkisini ve bu uygulamaların kent planlaması içerisindeki yaygınlığını ortaya koyabilmektir. Bu doğrultuda öncelikle kır göçünün kentlerdeki fiziksel yansıması olan gecekondular için çıkarılan mevzuatı dönemsel olarak ele alarak, 2000'ler sonrasının iki önemli yasal düzenlemesi olan ve ağırlıkla yine gecekondu alanlarını kendisine hedef alan 5393 sayılı Belediye Kanunun 73. Maddesi ile 6306 sayılı Afet Riski Altındaki Alanların Dönüştürülmesi Hakkında Kanuna odaklanmıştır. Ardından Resmi Gazete’ler üzerinden ulaşılabilen verilere göre ArcGIS üzerinden haritalar oluşturularak her iki uygulamanın mekansal yayılımı ortaya konmaya çalışılmıştır.

\section{Göçle Oluşmuş Yaşama Bölgelerine Yönelik Yasal Mevzuatın Gelişimi}

Kentlerde farklı göç süreçleri ile ve 1948'lerden itibaren ortaya çıkmaya başlamış olan gecekondu mahallelerine yönelik yasalar, konu aldıkları mahalleler için kararlar üretirken, ortaya çıkarıldıkları dönemin özelliklerine de bağlı olarak kentlerin mekânsal düzenini bütünlüklü olarak değiştirmişlerdir. Genel olarak birbirlerini takip eden ve bu bağlamda önemli içerik değişimleri taşımaktan çok ağırlıkla dönemin sorunlarına karşı ardışık ve birbirini telafi edici çözümler üretmeye çalışan yasal düzenlemeler, çoğu bugünkü gelişmeleri de yönlendiren kalabalık bir liste ortaya çıkarmışlardır (Tablo I). Göçle oluşmuş yaşama bölgelerindeki yapısal değişimleri yönlendiren tüm bu kararlar kentlerde günümüz uygulamalarının da temel olarak uğraştığı gelişmelerin kaynağı olmuşlardır.

İlk dönemlerde daha çok mevcut gecekonduları düzenlemeye ve yeni ortaya çıkabilecek gelişmeler için kontrollü alanlar yaratmaya yönelik olarak düzenlenmiş yasa içerikleri, çok daha ılımlı yaklaşımlar sergilemişlerdir. Bu süreçte kentleşmenin gereksindiği emek gücünü sağlayan kır göçünü kentte tutabilmenin bir yolu olarak geliştirilen arabulucu çözümler ile aslında pasif biçimde gecekondu yapımı desteklenmiştir (Erman, 20l0). Bu süreçte kent topaklarının yapısı da bu süreci desteklemiş ve büyük ve boş hazine arazileri ve terkedilmiş vakıf arazileri kaçak yapılaşmalar için en uygun alanlar haline gelmişlerdir. (Kurtuluş, 2010). Ancak 1930-1940'lı yıllarda "barakalaşma” biçiminde başlamış olan böyle bir yapılanma, giderek toprak mülkiyetinin ele alınış biçimi ve örgütsel ve yönetimsel karar süreçlerindeki eksiklikler nedeniyle boyut değiştirmeye başlamıştır. 1950-1960 döneminde, gecekondu nüfusu marjinal emek piyasası ile kent ekonomisinde yeni bir işlevsellik kazanmış ve kentteki konumunu güçlendirmiştir. Kaldı ki bu dönem gecekondunun politik boyutu da açığa çıkmıştır (Şenyapılı, 20l6). Böyle bir ortamda şekillenen mevzuat da giderek mülkiyet hakkı tanıyan affedici içerikleri ile, düzensiz ve sağııksız bir kentsel yapılanmanın önünü açmıştır.

1980'ler neo-liberal politikalar eşliğinde sadece göçle oluşmuş yaşama alanlarının durumunu değil, aynı zamanda tüm kentsel dinamikleri etkileyecek bir sürecin de başlangıcı olmuştur. Bu bağlamda dönemi Türkiye kentleşme deneyimi içerisindeki en radikal evre olarak tanımlamak mümkündür. Devlet bu dönemde birikim yaratma sürecini doğrudan kentsel mekâna bağlı seçimlere doğru yönlendirirken, büyük sermaye için farkIı alanlarda yer göstermeye de başlamıştır (Kurtuluş, 20I0). Göçle oluşmuş mahalleler de bu süreçte sermayenin gelişimine olanak tanıyacak önemli potansiyel alanlar olarak önem kazanmıştır. Bu stratejinin ilk basamağı olarak gecekondular af yasaları ile legal hale getirilmiş ve esasen son derece sorunlu açılımlar kazanmış bu yapının üzerinde imar hakları yaratılabilecek kentsel arsalar haline dönüştürülmesi sağlanmıştır. Ardından da mülkiyet haklarını esas alan düzenlemelerle göçle oluşmuş yaşama bölgeleri açısından bugün karşı karşıya gelinmiş pek çok sorunun kaynağı olan ıslah imar planları ortaya çıkmaya başlamıştır. Söz konusu planlar aracılığıyla kente eklemlenen göç alanları artık yatayda yayılmadan, düşeyde yükselmeye doğru evrilmişlerdir. Böyle bir sürece yetki ve sorumluluklarla ilgili yeni düzenlemeler de eşlik etmiştir.

1999 Marmara depremi ise o aşamaya dek kentleri arızalı bir biçimde yapılandırmış olan tüm gelişmelerin sorgulanmasını 
Tablo I. Türkiye'de kentsel dönüşüm uygulamalarına yön veren yasaların listesi

\begin{tabular}{|c|c|c|c|}
\hline $\begin{array}{l}\text { Kanun } \\
\text { no }\end{array}$ & Kanun adı & $\begin{array}{l}\text { Kanun } \\
\text { yil }\end{array}$ & Müdahale biçimi \\
\hline 5218 & $\begin{array}{l}\text { Ankara Belediyesine, arsa ve arazisinden belli bir kısmını mesken yapacaklara } 2490 \text { sayılı } \\
\text { Kanun hükümlerine bağıı olmaksızın ve muayyen şartlarla tahsis ve temlik yetkisi verilmesi } \\
\text { hakkında Kanun }\end{array}$ & 1948 & $\begin{array}{l}\text { Düzenleme } \\
\text { Önleme } \\
\text { Mülkiyet Hakkı }\end{array}$ \\
\hline 5228 & Bina Yapımını Teşvik Kanunu & 1948 & $\begin{array}{l}\text { Düzenleme, } \\
\text { Önleme } \\
\text { Mülkiyet Hakkı }\end{array}$ \\
\hline 5431 & $\begin{array}{l}\text { Ruhsatsız Yapıların Yıktırılması ve } 2290 \text { Sayılı Belediye Yapı Yollar Kanununun I3. Maddesinin } \\
\text { Değiştirilmesine Dair Kanun }\end{array}$ & 1949 & $\begin{array}{l}\text { Düzenleme } \\
\text { Önleme } \\
\text { Mülkiyet Hakkı }\end{array}$ \\
\hline 6188 & Bina Yapımına Teşvik Ve İzinsiz Yapılan Binalar Hakkında Kanun & 1953 & $\begin{array}{l}\text { Önleme } \\
\text { Mülkiyet Hakkı }\end{array}$ \\
\hline 7367 & Hazineden Belediyelere Devredilecek Arazi Arsalar Hakkında Kanun & 1959 & Önleme \\
\hline 634 & Kat Mülkiyeti Kanunu & 1965 & Düzenleme \\
\hline 775 & Gecekondu Kanunu & 1966 & $\begin{array}{l}\text { Mülkiyet Hakkı } \\
\text { Önleme }\end{array}$ \\
\hline 1164 & Arsa Üretimi ve Hakkında Kanun & 1969 & Önleme \\
\hline 1990 & Gecekondu Kanununda Bazı Değişiklikler Yapılması Hakkında Kanun & 1976 & Mülkiyet Hakkı \\
\hline 2805 & $\begin{array}{l}\text { İmar Ve Gecekondu Mevzuatına Aykırı Olarak Yapılan Yapılara Uygulanacak İşlemler Ve } 6785 \\
\text { Sayılı İmar Kanununun Bir Maddesinin Değiştirilmesi Hakkındaki Kanun }\end{array}$ & 1983 & Mülkiyet Hakkı \\
\hline 2981 & $\begin{array}{l}\text { İmar ve Gecekondu Mevzuatına Aykırı Yapılara Uygulanacak Bazı İşlemler ve } 6785 \text { sayılı İmar } \\
\text { Kanunu'nun Bir Maddesinin Değiştirilmesi Hakkında Kanun }\end{array}$ & 1984 & Mülkiyet Hakkı \\
\hline 2985 & Toplu Konut Kanunu & 1984 & Dönüşüm \\
\hline 3194 & İmar Kanunu & 1985 & $\begin{array}{l}\text { Dönüşüm } \\
\text { Yetki }\end{array}$ \\
\hline 3290 & $\begin{array}{l}3290 \text { Sayılı Kanun İle Bazı Maddeleri Değiştirilen Ve Bazı Maddeler Eklenen 298I Sayılı } \\
\text { Kanunun Uygulanmasına Dair Yönetmelik }\end{array}$ & 1986 & $\begin{array}{l}\text { Mülkiyet Hakkı } \\
\text { Dönüşüm }\end{array}$ \\
\hline 3366 & $\begin{array}{l}\text { 298I Sayılı Kanunun Bazı Maddelerinin Değiştirilmesi Ve Bu Kanuna Bazı Maddelerin } \\
\text { Eklenmesi Hakkındaki Kanun }\end{array}$ & 1987 & Mülkiyet Hakkı \\
\hline $34 \mid 4$ & $\begin{array}{l}\text { 22.05.1986 Tarih Ve } 3290 \text { Sayılı Kanun İle Değişik 24.02.1984 Tarih ve 298। Sayılı Kanunun } \\
\text { Bazı Maddelerinin Değiştirilmesi Hakkındaki Kanun }\end{array}$ & 1988 & $\begin{array}{l}\text { Mülkiyet Hakkı } \\
\text { Dönüşüm }\end{array}$ \\
\hline 3811 & $\begin{array}{l}775 \text { Sayılı Gecekondu Kanunun Bazı Hükümlerinin Değiştirilmesi Hakkında 03.05.1985 } \\
\text { Tarih Ve } 247 \text { Sayılı Kanun Hükmünde Kararname İle Bu Kanun Hükmünde Kararnamenin } \\
\text { İki Maddesinde Değişiklik Yapılmasına Dair I6.08.1985 Tarih Ve } 250 \text { Sayılı Kanun Hükmünde } \\
\text { Kararnamenin Değiştirilerek Kabulü Hakkındaki Kanun }\end{array}$ & 1992 & Yetki \\
\hline 4706 & $\begin{array}{l}34 \text { I4 Sayılı Kanunda Değişiklik Yapılması Hakkındaki Kanun Hükmünde Kararnamenin } \\
\text { Kabulüne Dair Kanun }\end{array}$ & 2001 & Mülkiyet Hakkı \\
\hline 4833 & 2003 Mali Yılı Bütçe Kanunu & 2003 & Mülkiyet Hakkı \\
\hline 5027 & Mali Yılı Bütçe Kanunu & 2003 & Mülkiyet Hakkı \\
\hline 5104 & $\begin{array}{l}\text { Kuzey Ankara Girişi Kentsel Dönüşüm Projesi Kanunu } \\
\text { Toplu Konut Kanununda ve Genel Kadro ve Usulü Hakkında Kanun Hükmünde }\end{array}$ & 2004 & $\begin{array}{l}\text { Mülkiyet Hakkı } \\
\text { Dönüşüm }\end{array}$ \\
\hline 5162 & Kararnamenin Eki Cetvellerin Toplu Konut İdaresi Başkanlığına Ait Bölümünde Değişiklik & 2004 & Yetki \\
\hline
\end{tabular}


Tablo I (devamı). Türkiye'de kentsel dönüşüm uygulamalarına yön veren yasaların listesi

\begin{tabular}{|c|c|c|c|}
\hline $\begin{array}{l}\text { Kanun } \\
\text { no }\end{array}$ & Kanun adı & $\begin{array}{l}\text { Kanun } \\
\text { yll }\end{array}$ & Müdahale biçimi \\
\hline & Yapılması Hakkında Kanun & & \\
\hline 5216 & Büyükşehir Belediyesi Kanunu & 2004 & Yetki \\
\hline 5226 & Kültür ve Tabiat Varlıklarını Koruma & 2004 & Dönüşüm \\
\hline 5237 & Türk Ceza Kanunu & 2004 & Düzenleme \\
\hline 5273 & $\begin{array}{l}\text { Arsa Ofısi Kanunu ve Toplu Konut Kanununda Değişiklik Yapılması ile Arsa Ofisi Genel } \\
\text { Müdürlüğünün Kaldırılması Hakkında Kanun }\end{array}$ & 2004 & Yetki \\
\hline Tasarı & Kentsel Dönüşüm ve Gelişim Kanunu Tasarısı & 2005 & Tasarı \\
\hline 5302 & İl Özel İdaresi Kanunu & 2005 & Yetki \\
\hline 5393 & Belediye Kanunu & 2005 & $\begin{array}{l}\text { Düzenleme } \\
\text { Dönüşüm } \\
\text { Yetki }\end{array}$ \\
\hline 5366 & $\begin{array}{l}\text { Yıpranan Tarihi ve Kültürel Taşınmaz Varıłıların Yenilenerek Korunması ve Yaşatılarak } \\
\text { Kullanılması Hakkında Kanun }\end{array}$ & 2005 & Dönüşüm \\
\hline 5377 & Türk Ceza Kanununda Değişiklik Yapılmasına Dair Kanun & 2005 & Yetki \\
\hline 5398 & $\begin{array}{l}\text { Özelleştirme Uygulamalarının Düzenlenmesine ve Bazı Kanun ve Kanun Hükmünde } \\
\text { Kararnamelerde Değişiklik Yapılmasına Dair Kanunda ve Bazı Kanunlarda Değişiklik Yapılması } \\
\text { Hakkında Kanun }\end{array}$ & 2005 & Mülkiyet Hakkı \\
\hline 5437 & 2006 YIlı Bütçe Kanunu & 2006 & Mülkiyet Hakkı \\
\hline Tasarı & Dönüşüm Alanları Hakkında Kanun Tasarısı & 2006 & Tasarı \\
\hline 5998 & Belediye Kanununda Değişiklik Yapılmasına İlişkin Kanun-73. Madde & 2010 & $\begin{array}{l}\text { Mülkiyet Hakkı } \\
\text { Dönüşüm } \\
\text { Yetki }\end{array}$ \\
\hline 6306 & Afet Riski Altındaki Alanların Dönüştürülmesi Hakkında Kanun & 2012 & $\begin{array}{l}\text { Mülkiyet Hakkı } \\
\text { Dönüşüm } \\
\text { Yetki }\end{array}$ \\
\hline 6360 & $\begin{array}{l}\text { On Üç İlde Büyükşehir Belediyesi ve Yirmi Altı İlçe Kurulması İle Bazı Kanun ve Kanun } \\
\text { Hükmünde Kararnamelerde Değişiklik Yapılmasına Dair Kanun }\end{array}$ & 2012 & Yetki \\
\hline 6360 & $\begin{array}{l}\text { On Dört İlde Büyükşehir Belediyesi ve Yirmi Yedi İlçe Kurulması İle Bazı Kanun ve Kanun } \\
\text { Hükmünde Kararnamelerde Değişiklik Yapılmasına Dair Kanun }\end{array}$ & 2012 & Yetki \\
\hline 6639 & Bazı Kanun ve Kanun Hükmünde Kararnamelerde Değişiklik Yapılması Hakkında Kanun & 2015 & Düzenleme \\
\hline $7 \mid 43$ & 3194 Sayılı İmar Kanunu Geçici Madde 16 & 2018 & Mülkiyet Hakkı \\
\hline
\end{tabular}

beraberinde getirirken, afet riskleri taşıyan bölgelerle birlikte, göçle oluşmuş ve nitelik sorunları bulunan yaşama alanlarının yeniden yapılandırılmasına yönelik arayışları da gündeme taşımıştır. Bu süreçte kentsel dönüşüm uygulamalarını doğrudan tarifleyen 2 yasa mevzuat tarihine eklenmiştir. Söz konusu yasalar 6306 sayılı Afet Riski Altındaki Alanların Dönüştürülmesi Hakkında Kanun ve 5393 sayılı Belediye Kanunun 73. Maddesidir. Söz konusu yasaların ortaya çıkmasına temel olan ortak zemini afet riskleri oluştursa da, bugüne dek gerçekleşmiş olan uygulamalar, öncelikle hedef alınan alanların göçle oluşmuş yaşama bölgeleri olduğunu göstermiştir.
İmar mevzuatına aykırı yapılaşan alanların dönüştürülmesini konu alan çok sayıda düzenleme ele alındığında, tam bir dönüşüm yasası biçiminde ortaya çıkmış olmasalar da içerdikleri kararlar açısından yasaların Türkiye tarihinde göçler ve gecekonduların ortaya çıkması ile birlikte beraber ilerleyen bir süreci takip ederek, bu alanlarda ve esasen kentsel yapılarda önemli etkiler yaratmış oldukları anlaşılabilmektedir. Bir başka ifade ile ülkemizde mevzuat gelişiminin bugün karşımızda bulunan kentsel yapıların var olan koşullarını yaratmada önemli roller üstlenmiş oldukları görülmektedir. $\mathrm{Bu}$ çerçevede son süreçte karşımıza gelmiş olan ve genel 
bir tanımlama ile Kentsel Dönüşüm yasaları olarak bilinen yasal düzenlemelerin ise esasen konu aldıkları gelişmeler ve kentsel sorunlar temelinde uzun bir tarihsel perspektifte biçimlenmiş kentsel yapıları onları biçimlendiren süreçlerle birlikte anlamayı gerektirdiği açıktır. Yasal düzenlemeler, ona eşlik eden kent planları ve uygulamalar kentsel gelişme dinamiklerinden bağımsız olmayıp, kentsel gelişmeleri anlama sürecine önemli veriler sağlamaktadır. Bu çalışmanın temel amacı da, böyle bir tarihsel mevzuat gelişimine son süreçte eklenmiş olan ve kendisini tüm ülke coğrafyasında yaygın bir uygulama alanı bulmuş 6306 sayılı Afet Riski Altındaki Alanların Dönüştürülmesi Hakkında Kanun ve 5393 sayılı Belediye Kanununun 73. Maddesi kapsamındaki etkiyi güncel verilerle ortaya koyarak kentsel gelişmeler açısından tarihsel bir belge yaratabilmektir.

\section{3 sayılı Belediye Kanunu'nun 73. Maddesi}

Türkiye Büyük Millet Meclisi tarafından 17 Haziran 2010 tarihinde kabul edilmiş olan ve 2005 tarihinde çıkartılan 5393 sayılı Belediye Kanununun 73. Maddesinin değiştirilmesine ilişkin yasa yerel yönetimlere "konut alanları, sanayi alanları, ticaret alanları, teknoloji parkları, kamu hizmeti alanları, rekreasyon alanları ve her türlü sosyal donatı alanları oluşturmak, eskiyen kent kısımlarını yeniden inşa ve restore etmek, kentin tarihi ve kültürel dokusunu korumak veya deprem riskine karşı tedbirler almak amacıyla kentsel dönüşüm ve gelişim projeleri uygulayabilir" şeklinde kentsel dönüşüm projesi uygulama yetkisi vermektedir. Bu şekilde yerel idareler inşaat şirketleri ile birlikte sadece fiziki düzenleme yapmakla sınırlı olmayacak biçimde özel mülke müdahalede de yetkili kılınmışlardır. Yukarıda sayılan amaçlar doğrultusunda ve bu alanın belediye veya mücavir alan sınırları içerisinde bulunması şartıyla (Kaya, 2009; Aydınlı ve Kaya, 20I3) dönüşüm projeleri yapılabilmektedir. Bu alanların kentsel dönüşüm alanı ilan edilebilmeleri belediyenin talebi ile Çevre ve Şehircilik Bakanlığının teklifi üzerine Bakanlar Kurulu tarafından karara bağlanmaktadır.

Yasa, söz konusu alanlarda standart imarlı bir alanda olduğundan farklı olarak özel bir çalışmayı gerektirmektedir. Bunun önemli bir nedeni ihtiyaç duyulan dönüşümler için yeterli ekonomik olanaklara sahip olamamalarıdır. Yapılacak uygulamalarda da kentsel dönüşümün sağladığı avantajların gerekli katılımın sağlanarak doğru ifade edilmesi de önemli bir unsurdur. Sonuç olarak amaçlanan imar faaliyetlerinin amaçları ile paralel bir biçimde daha sağlıklı bir yerleşim yerinin ortaya çıkarılmasıdır (Öngören, 20I3).

Yasa ile "kentsel dönüşüm ve gelişim proje alanı olarak ilan edilecek alanın; üzerinde yapı olan veya olmayan imarlı veya imarsız alanlar olması, yapı yükseklik ve yoğunluğunun belirlenmesi, alanın büyüklüğünün en az 5 en çok 500 hektar arasında olması, etaplar halinde yapılabilmesi hususlarının takdiri münhasıran belediye meclisinin yetkisine” bırakılmıştır. Bunun sonucunda üzerinde yapı olan veya imarlı alanlarda da dönüşüm uygulamaları yapılmasının önü açılmış; ayrıca belediyeler, tarım arazilerini ve imarsız boş alanları da yapılaşmaya açılmak için hukuki bir dayanak elde etmişlerdir (Aydınlı ve Kaya, 2013; Görün ve Kara, 2008).

Projeler kentsel alanlardaki kullanım ve mülkiyet haklarının alt gelir gruplarından üst gelir gruplarına doğru ve kamusal mülkiyetten özel mülkiyete doğru transfer edilmesine uygun bir zemin yaratmaları bağlamında kritik hale gelmişlerdir. Çünkü kentsel dönüşüm alanı ilanı için gerekli olan kriter, dönüşüm ve gelişim alanlarının 50.000 nüfus ve $\mathbf{5 0 . 0 0 0}$ metrekare ölçütleriyle sınırlandırılması biçiminde tanımlanmıştır. Dolayısıyla bu tür alanların belirlenmesi için sadece sayısal bir ölçüt ortaya konarak, dönüşüm/yenileme gerektiren sorunların varlığı geri plana itilmiştir (Karasu, 2009; Özden, 2008; Tezcan ve Zengin Çelik, 2017).

Söz konusu düzenleme de tartışmalı açılımları ile farklı eleştirilere konu olmuştur. Zira bu düzenleme de "kentsel dönüşüm ve gelişim proje alanı" olarak belirlenecek alanların, "imarlı veya imarsız", "üzerinde yapı olan veya olmayan" alanlar olabileceğini ve planlarda kentsel gelişmeye açılmamış alanların da "kentsel dönüşüm ve gelişim proje alanı" olarak tanımlanabileceğini ifade etmektedir. Yasa'da Büyükşehir Belediyesi sınırları içerisinde yer alan ilçe belediyelerinin taleplerinin olmamasına karşın Büyükşehir Belediyesi uygun gördüğü alanlarda "kentsel dönüşüm alanı" ilan edebileceğinin belirtilmiş olması da yerelleşme ve katılımcı planlama açısından önemli bir sorun başlığı haline gelmektedir. Bu konuda Büyükşehir Belediyeleri'ne verilen geniş yetkilere rağmen, ilçe belediyelerinin yetkisiz kılınması ise geçerli mevzuatta yer alan Belediye ve Büyükşehir Belediyesi yasaları açısından sorun yaratmaktadır. Diğer yandan kentsel dönüşüm alanı olarak ilan edilmiş yerlerdeki proje bilgilerinin halka duyurulması, askıya çıkarılması ve itirazların nasıl yapılacağı gibi konulardaki belirsizlikler de planlamanın şeffaflık/açıklık ilkesine aykırı bir durum sergilemektedir. Yasa ile I/I00.000 ölçekli Çevre Düzeni Planlarında veya yerleşimlerin nazım planlarında "tarımsal niteliği korunacak alan" veya "iskan dışı alan" olarak tanımlanmış alanlarda "kentsel dönüşüm ve gelişim proje alanı" ilan edilebilmesine imkan veren açılımların yer alması da planların kademeli birlikteliği ilkesi açısından sorunlu bir başka konu başlığı olarak ele alınmaktadır. Bütün bunlarla birlikte söz konusu düzenlemenin kendine ağırlıkla hedef aldığı göç ve yoksulluk alanlarında yaşayanları başka alanlara sürükleyecek bir yapıda oluşu da eleştirilerin odağına alınan bir başka başlıktır. Bu kapsamda proje alanlarının ağırlıkla yüksek rant beklentisi olan yerlerden seçilmesi nedeniyle bölgeler arası eşitsizlik yaratacağı; ödenebilir konut ile kiracı haklarında belirsizlik ortaya çıkaracağı, ekonomik koşulları içeren bir soylulaştırmaya ve bu şekilde yeni sınıfsal ve mekânsal ayrımlara neden olunacağı ifade edilmektedir. Uygulamaların sadece ekonomik bir içerik taşıdığına ve konu aldıkları toplulukların kendine özgü sosyal nitelik ve şartlarının dikkate alınmadı̆̆ına dikkat çekilmektedir. Bir diğer konu ise tanımlamalar üzerindeki belirsiz- 
liklerdir. Minimum alan miktarının belirlenmesi, kentsel dönüşümün tanımında yer alan eskimenin hangi kriterlerle ortaya konduğu, tasarımın alana özgü özelliklerin devam edeceği mi yoksa göz ardı mı edileceğinin bilgisi tanımlarda yer almamaktadır. Bilgilendirme araçları ile vatandaşların, meslek odalarının ve üniversitelerin katılımlarının başarılı bir kurgu ile yapılamaması da başka bir eleştiridir (Türkiye Planlama Okulları [TUPOB], 2010; Bektaş, 20I4; Genç, 20I4; Güzey, 20I2, Özden, 20I0).

Çalışma kapsamında ulaşılabilen verilere göre Türkiye'deki 8 I ilin 34 tanesinde, ülkedeki illerin yaklaşık \%42'sinde bu yasal düzenleme ile riskli alan ilanı ilanı bulunduğu tespit edilmiştir. Ulaşılabilen verilere göre toplamda 23 I mahallede yaklaşık I5,268 hektarlık bir alan 20II-20I8 yılları arasında kentsel dönüşüm ve yenileme alanı ilan edilmiştir. Bu genel bilgilerle birlikte riskli alan ilan sayılarının Türkiye genelindeki dağılımı ArcMap'te 20II-2018 yılında ilana çıkan kentsel dönüşüm alanları verilerinin işlenmesi ve bu verilerin doğal aralıklar (natural breaks) sınıflandırma yöntemiyle oluşturulan haritası Şekil I'de görülmektedir. Bu dağılıma göre Ankara ve Gaziantep en yüksek veriye sahip İller olurken onu İzmir, Kayseri ve Şanlıurfa İlleri izlemektedir (Tezcan, 2020).

\section{6 sayılı Afet Riski Altındaki Alanların Dönüştürülmesi Hakkında Kanun}

31.05.2012 tarihli Resmi Gazete'de yayımlanarak yürürlüğe giren yasanın, Türkiye'nin önemli bir sorunu olan afet karşısındaki yükümlülükleri bakımından önemli bir adım niteliği taşıdı̆̆ını ileri sürmek mümkündür. Çünkü yasanın gerekçe metninde "Ülkemizde başta deprem olmak üzere afet riskinin yüksek olmasına karşın yapı stokumuzun büyük bir kısmının güvensiz ve imar mevzuatına aykırı olması, kaçak yapılaşmanın çok fazla olması nedenleriyle afetler oluşmadan önce gerekli tedbirlerin alınmasına yönelik bir mevzuata acil olarak ihtiyaç duyulmaktadır" ifadesi yer almaktadır. Bu içerik mevcut yapı stokunun çoğunun, 1998 deprem yönetmeliğinden önce yapılmış olması temelinde ve bu kapsamda Şimşek'in (2016) de ifade ettiği şekliyle yaklaşık 19 milyon konutun 14 milyonunun risk taşıyabileceğini göstermektedir. Öte yandan zaten Türkiye kentleşme pratiğinin önemli ölçüde kaçak ve sağııksız bir yapı stokuna temellenen içeriği düşünüldüğünde afete odakı bu içerik son derece meşru bir nitelik kazanmaktadır. Ne var ki, gücünü son derece geçerli koşullardan alıyor olsa da kentsel dönüşüm mevzuatının kent planlama çalışmalarının ilkesel zemini açısından ve konu aldığı geniş kitleler temelinde tedirgin edici özellikler yaratmış olduğu ve bu kapsamda farklı çevrelerce eleştirilere konu olduğu da görülmektedir.

Bu noktada yasanın 1980 sonrası yerelleşmiş planlama süreçlerini tekrar merkezi uygulamalara dönüştüren içeriği önemli bir tartışma başlığı olmuştur. Yasa ile "afet riski altındaki alanlar ile bu alanlar dışındaki riskli yapıların bulunduğu alanlarda" sağııklı ve güvenli yaşama çevreleri oluşturmak amacıyla "iyileştirme, tasfiye ve yenilemelere dair usul ve esasları düzenlenmekte; riskli yapıların bulunduğu taşınmazlara ilişkin her tür ve ölçekteki planı yapma, yaptırma ve onaylama yetkisi Çevre ve Şehircilik Bakanlığı'na verilmiştir. Bu durumu yasanın maddelerinde yer alan riskli alan tespitinde "Bakanlıkça lisanslandırılan kurum ve kuruluşların yetkili olması ve riskli yapı tespitine ilişkin yapılan itirazların incelenmesinde görevli olan teknik heyette Bakanlık temsilcilerinin yer alması" hükmü de güçlendirmiştir (Daşkıran ve Ak, 20I5). Yasanın bu merkeziyetçi tutumu ve kentsel dönüşüm projelerinin yerel idarelerce hazırlanmış planlara ve kararlara uymayacak bir içerikte yukarıdan dayatılarak ortaya çıkarılmaları, kent planlama disiplini açısından önemli bir sorun olarak tanımlanmaktadır. Bir başka ifade ile yerel idarelerce hazırlanmış imar planlarının ve bu kapsamda özellikle de kent ölçeğinde ve bütünlüklü olarak ortaya çıkmış olan planların alansal ya da bölgesel uygulamalarla bütünlük ve dengelerinin bozulacağı kabul edilmektedir.

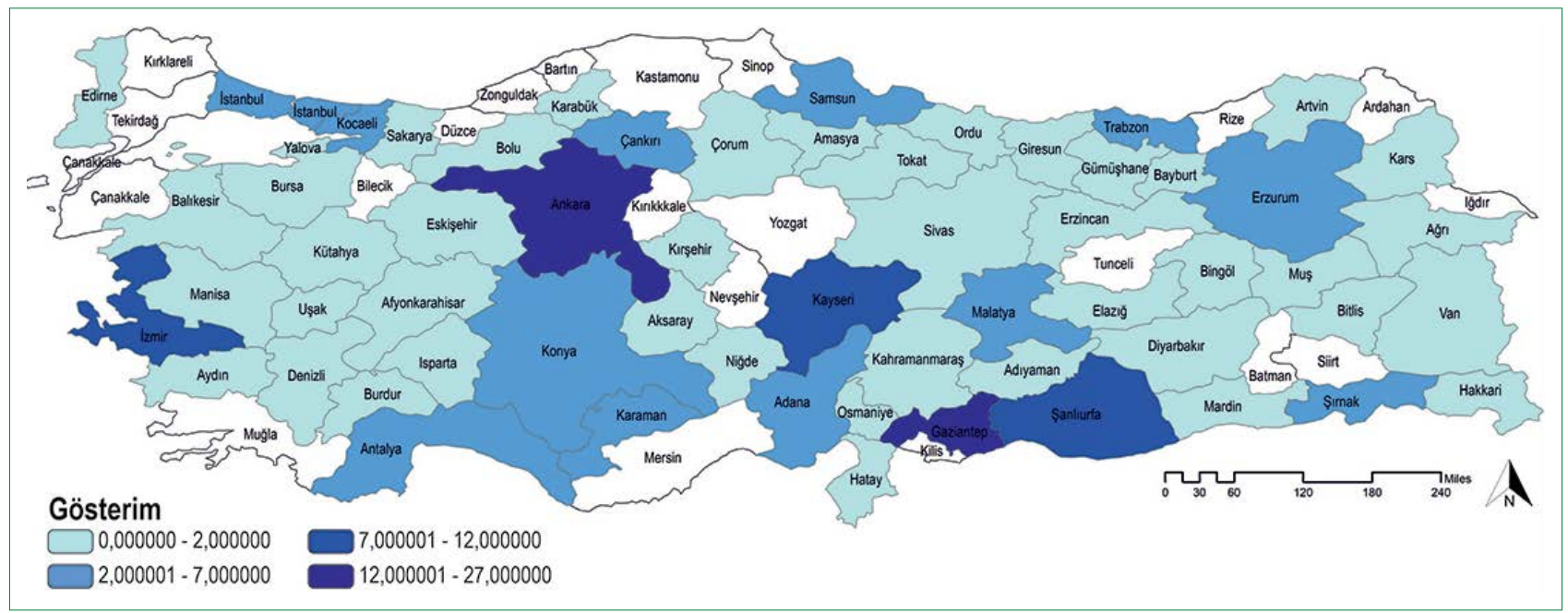

Şekil I. 73. Madde ile ilan edilen kentsel dönüşüm alanlarının Türkiye dağıımı (20 I I-20 I8). 
Bu bağlamda özellikle de doğal ve kültürel nitelikleri ile öne çıkan alanlarda ve daha önce hazırlanmış koruma amaçlı imar planları açısından doğacak uyumsuzluklara neden olacak içerik, gündeme gelen çokça vaka üzerinden eleştiriye uğramaktadır (Demirkol ve Bereket Baş, 2013; Özkaya Özlüer, 2018; Gürcanlı, Yönez ve Yönez, 20I7; Genç, 2014).

Yasa açısından ele alınan en önemli sorunlardan biri de risk ve riskli yapı tanımlamaları açısından ortaya çıkmaktadır. Yasanın 3. maddesinde; “f) (Değişik: RG-2I/6/2019-30808) Riskli alan: Zemin yapısı veya üzerindeki yapılaşma sebebiyle can ve mal kaybına yol açma riski taşıyan, Cumhurbaşkanınca kararlaştırılan alanı, g) Riskli yapı: Riskli alan içinde veya dışında olup ekonomik ömrünü tamamlamış olan ya da yıkılma veya ağır hasar görme riski taşıdığı ilmî ve teknik verilere dayanılarak tespit edilen yapıyı veya yapıları ifade eder" denilmektedir. Ancak yasa bu tanıma uygun yapılar dışında yani risk taşımayan yapıları da uygulama bütünlüğü açısından uygulamalara dahil etmektedir (Daşkıran ve $\mathrm{Ak}, 20 \mathrm{I5})$. Bu yapısı ile yasanın mülkiyet hakkına müdahale ediyor olması ve yasa kapsamında "mülkü boşalttırmak amacıyla, en minimum" hizmetler olan elektrik, su ve doğalgazın ilgili kurum ve kuruluşlar tarafından durdurulmasını düzenleyen maddesi ile barınma ve konut hakkına aykırı bir içerik yaratması (Demirkol ve Bereket Baş, 20I3) önemli bir konu haline gelmektedir.

Yasanın riskli yapı tanımlaması ile birlikte gündeme getirdiği en önemli konulardan birisi de parsel ölçeğindeki yenileme uygulamalarıdır. Nitekim yasa kentsel dönüşümü parsel ölçeğine indirgeyen ve bu şekliyle de müteahhit firmalar aracılığıyla inşaat piyasasında önemli bir hareketlilik yaratan içeriği ile aslında önemli bir yapı ve nüfus yoğunluğu değişimine sebep olmaktadır. Bu çerçevede kent planlarında bütüncül olarak yapılandırıldığı kabul edilen sosyal ve teknik altyapı yatırımları açısından kişi başına düşen standartların ve kentsel olanakların giderek azalması sorunu ile karşı karşıya gelinmektedir (Zengin Çelik ve Çilingir, 2017).

Genel olarak bakıldığında yasaya dair eleştirilerin çoğunun sağlıklı bir kentsel yenilemenin sağlanamaması, uygulamaların özellikle metropol kentler başta olmak üzere yeni rant alanları yaratması, tüm süreçte bilim çevrelerinin görüşüne başvurulmaması ve afet riskine ilişkin düzenlemeler ile kentsel dönüşüme ilişkin hükümlerin aynı yasa ile yapılmış olmasının yarattığı çelişkiler bağlamında ortaya çıkmış olduğu görülmektedir. Bu kapsamda ağırlıklı olarak konut hakkını önceleyen kapsamlı bir kentleşme politikasının ortaya konmamış olması, kentte yaşayan herkesin mülkiyet hakkına müdahale edecek bir içeriğin temel hak ve özgürlüklere aykırı olması önemli bir tartışma başlığı yaratmış bulunmaktadır. 6306 sayılı Yasanın 3. maddenin 7. fıkrasında riskli yapılar dışında kalan diğer yapıların da uygulama bütünlüğü bakımından yıkılmasına olanak tanınması, bu yapıların belirlenmesi kriteri olarak ise "Bakanlık tarafından gerekli görülen” ifadesinin kullanılması yasa ile ortaya konan merkezi- yetçi tutumu desteklemekte ve neredeyse ülkenin tamamında kentsel dönüşüm alanı ilan etme olanağını yaratan bu tutumda içerisinde TOKI'nin tek otorite olarak görülmesi tedirgin edici bir durum olarak ele alınmaktadır. Öte yandan Yasanın 3. maddesinde tanımlanan rezerv yapı alanlarının kapsamının idareler tarafından zeytinlik, mera, orman, kıyı, askeri bölge ve sit alanlarını da içerecek biçimde genişletilebilmeye olanak tanıması hususu bir başka eleştiri konusunu oluşturmaktadır. Bu kapsamda arkeolojik ve tarihi sit alanlarında yapılacak tespitlerde değerlendirmelerin yeterli düzeyde açıklayıcı bilimsel kriterler içermiyor oluşu doğrultusunda yeraltı ve yerüstü varlıkların ve önemli bir kültürel birikimin yok olmasına neden olunacağı da yine yasanın önemli eksikliklerinden biri olarak değerlendirilmektedir (Demirkol ve Bereket Baş, 2013; Özkaya Özlüer, 2018; Gürcanlı, Yönez ve Yönez, 20I7; Genç, 20I4).

Bu eleştirilerle birlikte ilk çıktığı 2012 yılından günümüze kadar Türkiye'nin neredeyse tamamında yasa kapsamında riskli alan ve kentsel dönüşüm alanı ilanlarının yapılmış olduğu görülmektedir. Yapılan çalışma kapsamında ulaşılabilen verilere göre Türkiye'deki 8I ilin 52 tanesinde, yani ülkedeki illerin yaklaşık \%64'ünde riskli alan ilanı bulunmaktadır. Toplamda 522 mahallede yaklaşık 13.300 hektarlık bir alan 2012-2018 yılları arasında riskli alan ilan edilerek kentsel dönüşüm uygulamalarının konusu olmuştur. Riskli alan ilanı kararı en çok 2013 yılında Resmi Gazetede yer almıştır. Bu genel bilgilerle birlikte riskli alan ilan sayılarının Türkiye genelindeki dağııımı ArcMap'te 2012-2018 yılında ilana çıkan kentsel dönüşüm alanları verilerinin işlenmesi ve bu verilerin doğal aralıklar (natural breaks) sınıflandırma yöntemiyle oluşturulan haritası Şekil 2'de görülmektedir. Bu dağılıma göre İstanbul en yüksek veriye sahip II olurken, onu İzmir, Ankara, Kayseri ve Adana illeri izlemektedir (Tezcan, 2020).

\section{Türkiye'de Resmi Gazetede İlan Edilmiş Riskli Alan ve Kentsel Dönüşüm Alanları}

Türkiye'de "kentsel dönüşüm” uygulamalarına ilişkin süreç içerisinde pek çok yasal düzenleme olmasına rağmen son zamanlarda ağırıkla göçle oluşmuş yaşama bölgelerini konu alan iki önemli yasa 6306 Sayılı Afet Riski Altındaki Alanların Dönüştürülmesi Hakkında Kanun ile 5393 Sayılı Belediye Kanunun 73. maddesi uygulamalarıdır. Gerek etkiledikleri alansal ve gerekse sosyal büyüklüğü tanımlayabilmek üzere söz konusu yasalar aracılığıyla ortaya çıkmış uygulamaların nasıl yayıldıkları ve yıllara göre dağılımları ArcGIS programı üzerinden haritalandırılmıştır. 73. Madde uygulamalarında "kentsel dönüşüm ve gelişim alanı” olarak belirlenen ve Resmi Gazete'de kentsel dönüşüm alanı olarak ilana çıkan alanlar tespit edilmiş; tarih ve mahalleleri bir tablo haline getirilmiştir. 6306 sayılı yasada ise "riskli alan" olarak Resmi Gazete'de ilan edilmiş alanlar tespit edilmiş ve aynı şekilde tarih ve mahalle sayıları tabloya işlenmiştir. Ardından Google Earth'den de faydalanarak alan- 


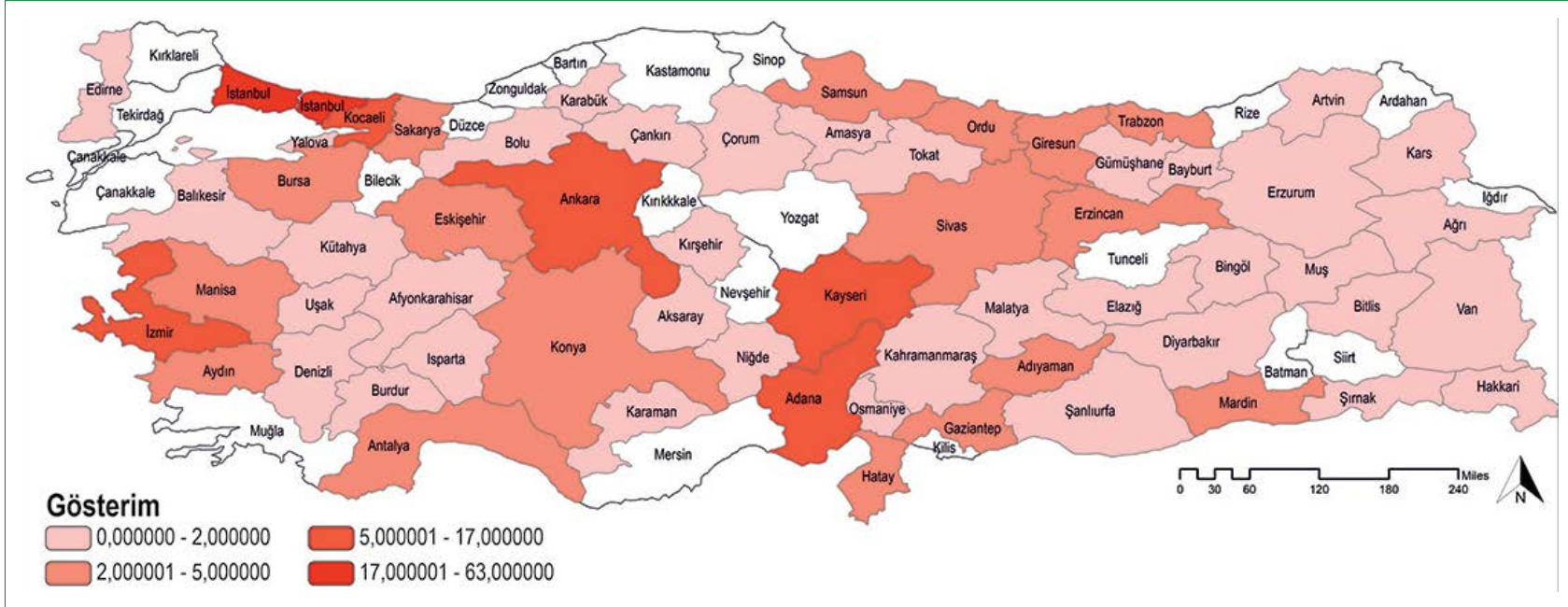

Şekil 2. 6306 Sayılı Kanunla Riskli Alan Illanlarının Türkiye dağııııı (2012-20।8).

lar yerinde tespit edilerek ilanda yer alan sınırların yaklaşık merkez noktaları seçilerek sembolik bir yer seçilip işaretlenmiştir. Resmi Gazete taramasının ardından elde edilen ve tablolaştırılan veriler bu noktalara atanarak kentsel dönüşüm projelerinin hangi kanunla ilan edildiği, ilan tarihleri ve mahalle büyüklüklerini içeren haritalar oluşturulmuştur.

\section{Türkiye'de Her İki Yasanın Uygulamalarının Dağıımı}

Resmi Gazete'de yer alan "riskli alan” veya "kentsel dönüşüm alanı" olarak ilana çıkmış yerler kanunların çıktığı yıllardan 2019 yılına kadar olan süre içerisinde yıl bazında haritalandırılmıştır. Şekil 3'te her iki uygulamanın Türkiye genelindeki dağıımı iller bazında gösterilmiştir. Veriler uygulamaların temellendiği yasalar açısından bölgesel farklılıklar gösterdiğini ortaya koymuştur.
Türkiye genelinde taranan ve ulaşılabilen bilgilere göre toplamda 359 adet kentsel dönüşüm uygulaması kararı bulunmaktadır. Bunların \%58'ini 6306 sayılı kanunla ilan edilen riskli alanlar oluştururken \%48'i 5393/73. Madde uygulamalarıdır. Bu uygulamaların konu aldıkları alanların özelliklerine bakıldığında ise çoğunlukla göç sonucu oluşmuş mahallelerin öne çıktığı görülmektedir. Bu bölgeler 6306 sayılı yasaya göre doğrudan binanın riskli olduğu alanlar olmakla birlikte alan olarak da risk taşımaktadır.

Öte yandan ilan edilmiş alanların nitelikleri değerlendirildiğinde, yasanın ortaya çıkma amacına uygun olarak deprem riski taşıyan alanların çoğunlukta olduğu görülmektedir. Bunların çok az bir kısmı sanayi ya da boş alan olarak konut dışı fonksiyona sahiptir. Projelerin deprem riskleri açısından coğ-

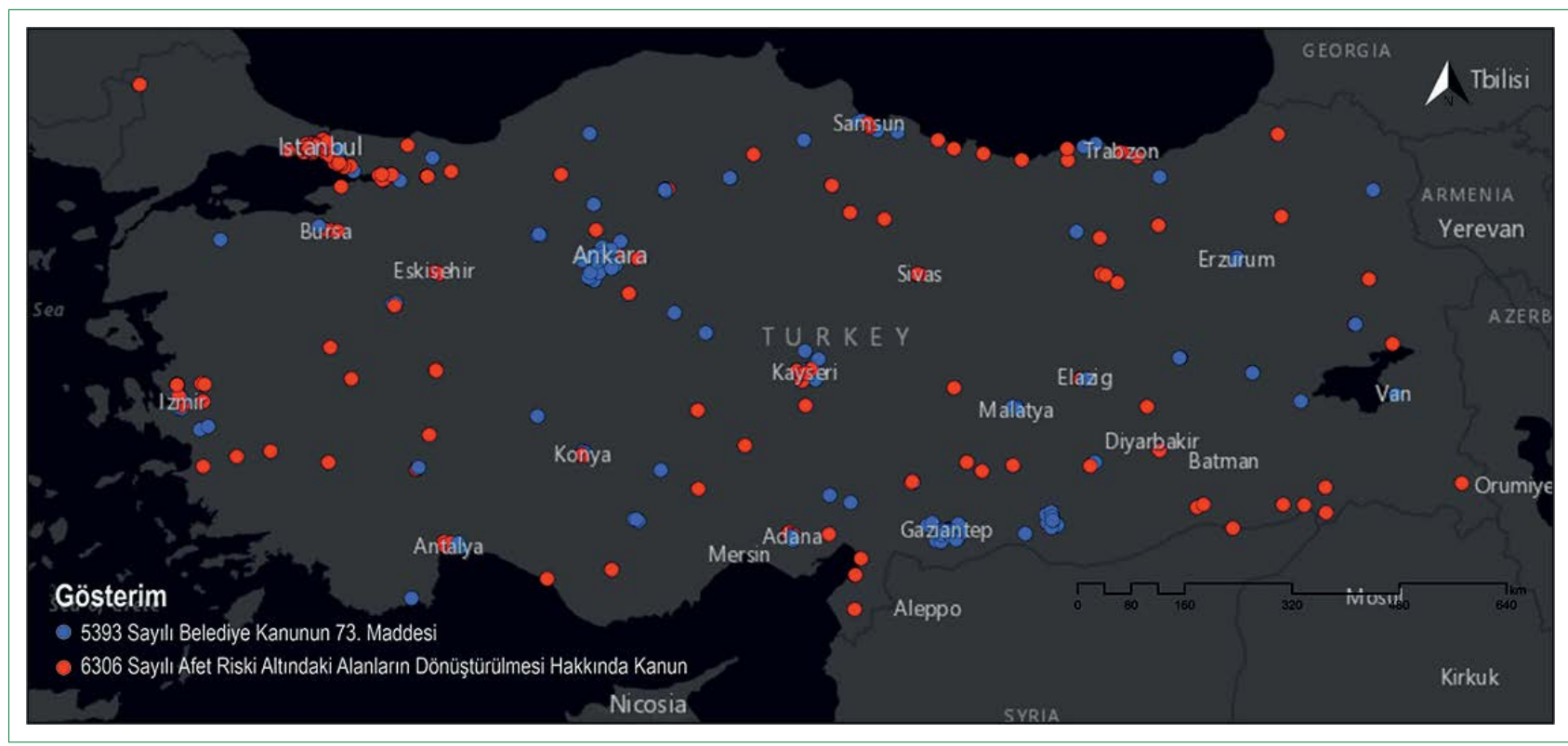

Şekil 3. Uygulamaların ilan kararlarının illere göre dağııımı. 
rafi şartlarla nasıl ilişkilendiği incelendiğinde ise, T.C. İçişleri Bakanlığı Afet ve Acil Durum Yönetimi Başkanlığının [AFAD] (2019) yayınladığı son afet riski haritasına bağlı olarak özellikle 37 ilin risk durumunun yüksek olduğu ve bu ilerde de kentsel dönüşüm projelerinin bulunduğu izlenmektedir.

Ayrıca 6360 sayılı yasa kapsamında belirlenen uygulama alanlarının niteliği açısından bir inceleme yapıldığında riskli alan ilan edilen alanların çoğunu konut alanlarının oluşturduğu, bununla birlikte yaklaşık \%3'lük bir kısmının ise sanayi vb. kentsel kullanımların oluşturduğu bulgulanmaktadır. 73. Madde uygulamalarına bakıldığında ise konut dışı fonksiyonlar toplam ilanların yaklaşık \%3,5'ini oluşturmaktadır. Bu veri her iki yasanın da kendisine ağırlıkla konut alanlarını hedef aldığını göstermesi açısından önemlidir.

Kırdan kente göçün en yoğun yaşandığı iller (Anadolu Ajansı [AA], 2008) olan İstanbul, İzmir ve Ankara'nın daha detaylı gösterimi ise Şekil 4'teki gibidir. Buna göre İstanbul'da 6306 sayılı yasanın uygulamalarının daha yoğun olduğu görülmektedir. Ankara'da 73. madde uygulamaları görece daha geniş bir alanda yer bulurken İzmir'de ise her iki uygulama sayıca neredeyse eşit bir dağılıma sahiptir. Ayrıca uygulamaların söz konusu üç kentte de, çeperlerde bulunabilmekle birlikte merkezde yoğunluk kazandığı görülmektedir. Projelerin alan niteliklerinin dağılımlarına bakıldığında ise cezaevi gibi bir fonksiyon dışında kararların konut alanlarına yönelik olduğu görülmektedir.

\section{Türkiye'de Her İki Yasanın Uygulamalarının Yıllara Göre Dağılımı}

Kentsel dönüşüm uygulamalarından her iki yasanın da ilan edildiği tarihlerden itibaren Resmi Gazete'de riskli alan/kentsel

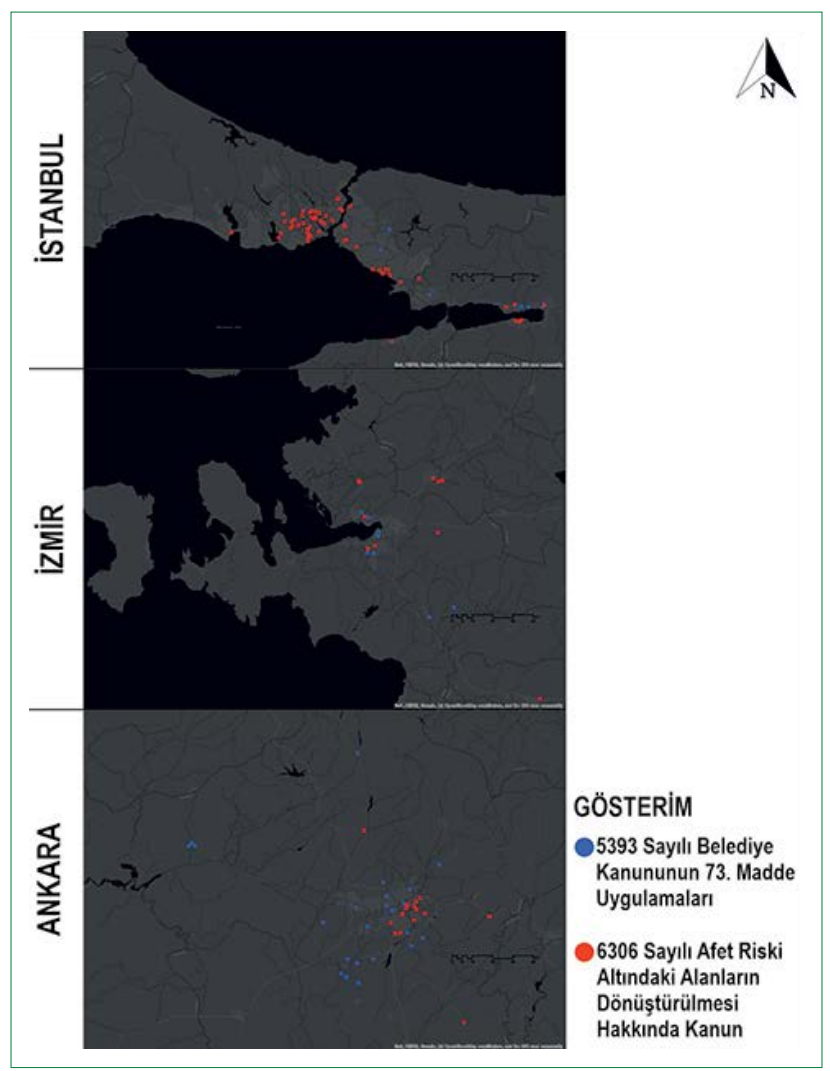

Şekil 4. Uygulamaların ilan kararlarının detaylı gösterimi.

dönüşüm alanı olarak ilana çıkmış olduğu alanların yıllara göre dağılımları Şekil 5'te gösterilmiştir. Buna göre yıllar itibarıyla kentsel dönüşüm kararlarının illere yayılması izlenebilmektedir. Her yıl yeni alanlar ilan edilmesine rağmen özellikle ilk çıktıkları dönemde sayıca fazla oldukları gözlenmektedir.

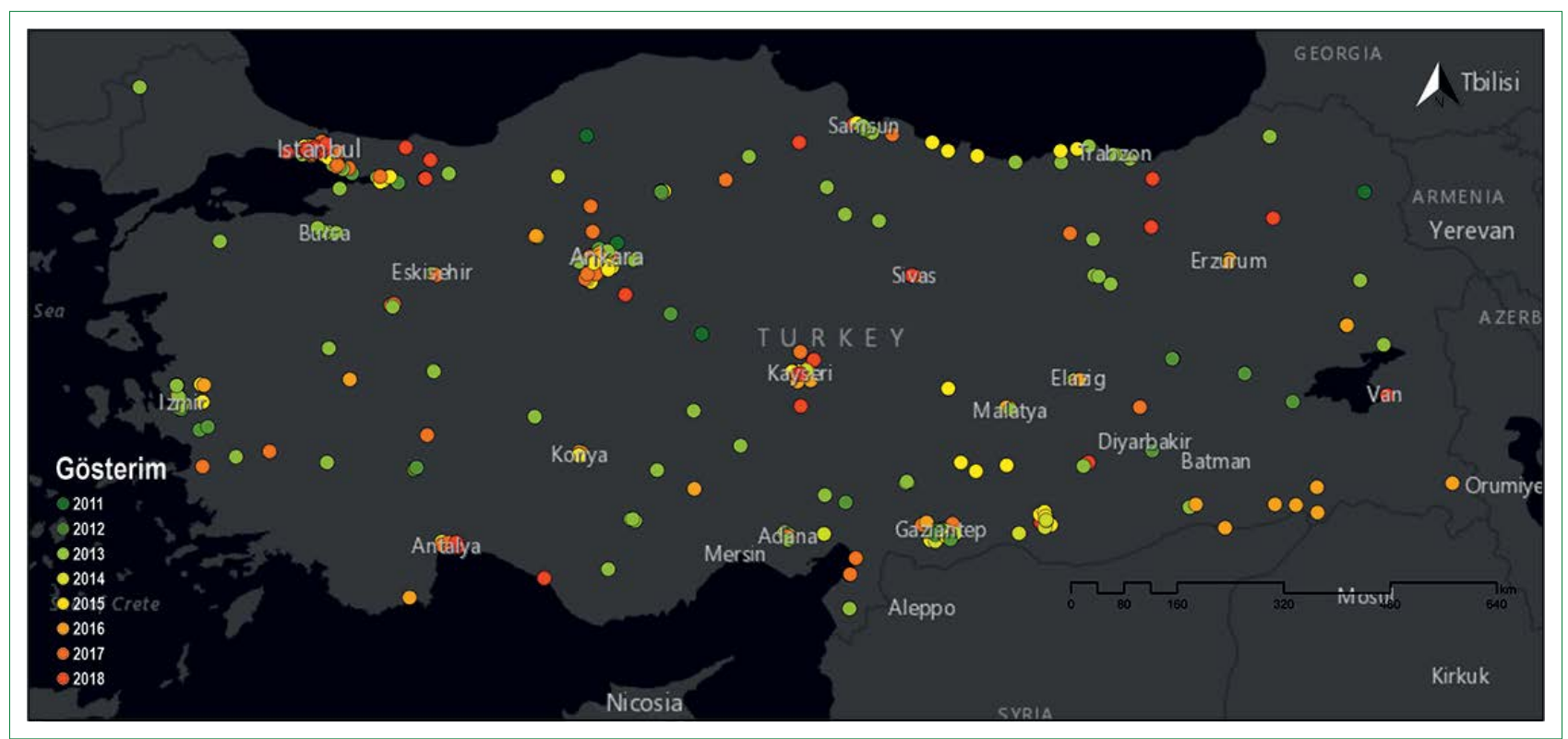

Şekil 5. Uygulamaların ilan kararlarının yıllarının illere göre dağıımı. 
İstanbul, Ankara ve İzmir illerinin detaylandırılmış görünümleri ise Şekil 6'daki gibidir. Buna göre İstanbul'da 2010-2018 yılları arasında geniş bir dağılım varken, Ankara ve İzmir'de ilk yıllarda yoğunlaşmaktadır. İstanbul kentsel dönüşüm ilanlarının ağırlıkla 2013 (\%36), 2016 (\%।8) ve 2018 (\%।8) yıllarına tarihli olduğu görülmektedir. Ankara'da kentsel dönüşüm kararları yoğunluk sırasına bakıldığında ise 2013 (\%32), 2017 (\%23) ve 2015 (\%2I) yılı tarihli oldukları tespit edilmiştir. İzmir'deki ilan kararları tarihlerine bakıldığında en yoğun iki yılın 2012 (\%46) ve 2013 (\%40) olduğu görülmüştür. Bu durum, kanunların çıktığı ilk dönemde yoğun bir başvurunun olduğunu göstermekle birlikte sonuçlarının okunmaya başladığı 2017 yılı sonrasında İzmir'in yeni ilanlarının olmadığı; İstanbul ve Ankara'nın bu deneyimlerin sonucunda kentsel dönüşümü bir strateji olarak kullanmaya devam ettikleri görülmektedir.

Kentsel dönüşüm uygulamalarından her iki yasanın da çıktıkları yıllardan itibaren ilana çıkmış alanlarının yıllara göre dağılımları Şekil 7'de gösterilmiştir. Çıktığı yıldan itibaren 73. Madde uygulamaları fazla inişli çıkışlı bir seyir izlemezken 6306 sayılı yasanın uygulamaları kanunun çıktığı yılın hemen ardından en yüksek noktasına ulaşmış; ardından o da sabite yakın bir seyir izlemiştir.

\section{Türkiye'de Her İki Yasanın Uygulamalarının Kapsadıkları Mahalle Sayısına Göre Dağııımı}

İlan edilen alanların toplam büyüklüklerine bakıldığında ise ülke genelinde yaklaşık 28.569 hektarlık bir alanda kentsel dönüşüm kararı alınmış olduğu bulgulanmaktadır. Bu projelerin Resmi Gazete'de belirtilen mahallelerin sayıca tablolaştırılmasının ardından kapsadıkları mahalle sayılarına göre dağılımları ulaşılan veriye göre Şekil 8'deki gibidir. Veriler uygulamaların özellikle göçle oluşmuş ve gecekondu oranının da yoğun olduğu illerde artış gösterdiğini ortaya koymaktadır. Bölgesel anlamda kapladıkları alanın ve dolayısıyla projelere dahil olan mahalle sayısının müdahale alanının da geniş olduğunu ortaya koyacağı varsayımı ile bu dağılım yapılmıştır. Ege, Marmara ve Güneydoğu illerinde mahalle sayısı daha yüksek projelerin olduğu görülmekle beraber I ve 2 mahalleyi içeren dönüşüm alanlarının olması proje yapma eğiliminin sadece büyük kentlerle sınırlı kalmadığını ülke geneline yayıldığını göstermektedir.

Mahalle sayılarının dağılımına bakıldığında ise proje büyüklüklerine göre ilana çıkmış proje alanlarının \%58'i I, \%20'si I ve \%।0'u 3 mahalle olmak üzere bu dağılım içerisindeki en geniş pay (\%88) 3 ve altı mahalle sayısına sahip projelere aittir. Proje alanlarının kapsadıkları alanlar bakımından daha geniş olduğu 4 ve 9 mahalleyi kapsayan projeler ise toplam projelerin \%9'luk bir dilimini oluşturmaktadır. Burada aykırı değer sergileyen mahalle sayısına göre en yüksek projeler ise \%3'lük bir dilimi kapsayan 10 ve üzeri mahalleyi içeren proje alanlarıdır. Böyle bir veriyi, riskli alan ilanı ile projelere

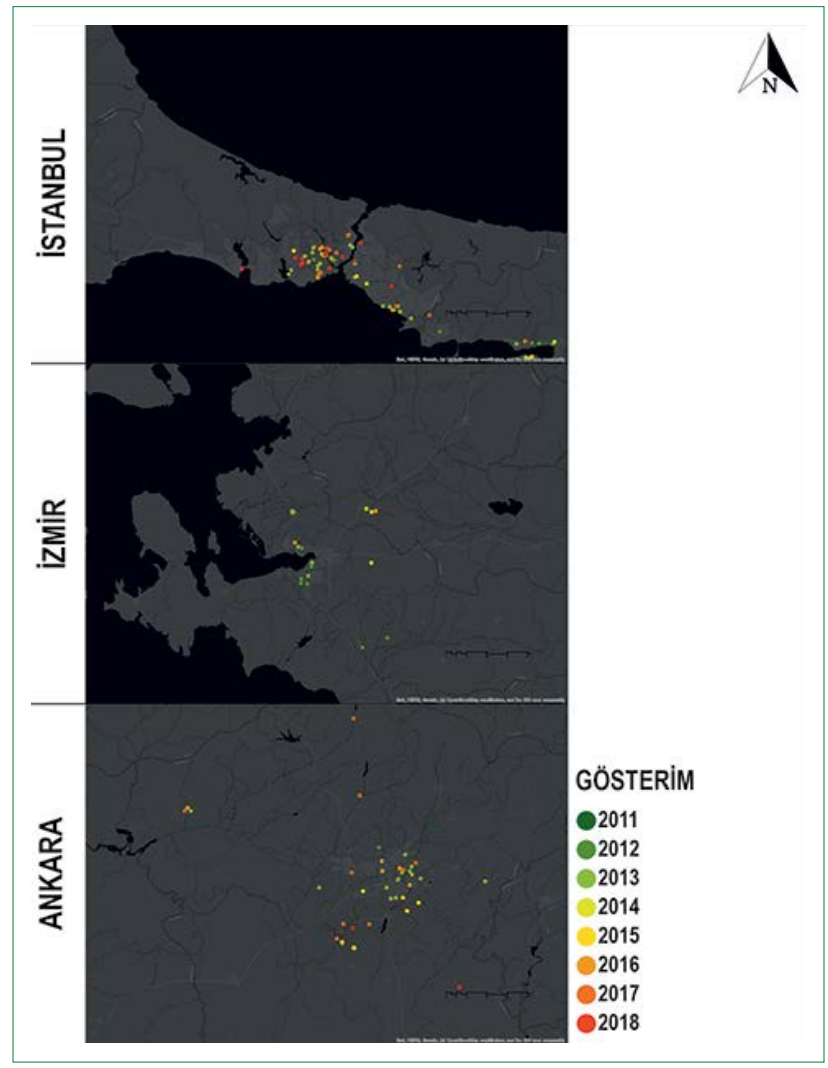

Şekil 6. Uygulamaların yıllara göre dağıımının detaylı gösterimi.

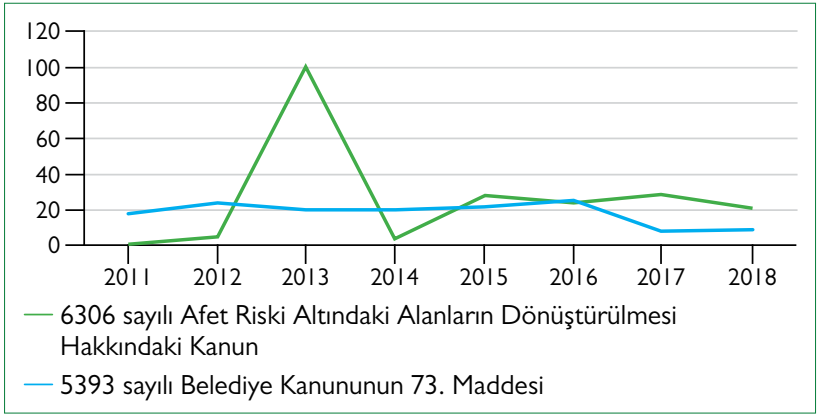

Şekil 7. İki yasal uygulamanın yıllara göre dağılımı.

konu edilen alanların kentler içerisinde genel olarak en çok I ya da 2 mahalleden oluşan, bu bağlamda parçalı ve noktasal oldukları biçiminde yorumlamak mümkündür. Bu alanların İstanbul, Ankara ve İzmir illeri üzerindeki dağılımının detayı ise Şekil 9'da gösterilmiştir.

\section{Sonuç ve Değerlendirme}

Türkiye kentleşme pratiği içerisinde kentsel arsa her zaman yarattığı ekonomik değer üzerinden önemli bir değişim aracı olmuştur. Bu durum kentlerin giderek üretim mekânından tüketim mekânına dönüştüğü 1980 sonrası süreçte kentsel mekânın, sermayeyi geliştirmenin bir aracı haline gelmesini sağlarken, kentler inşaat piyasası aracılığıyla daha hızlı ve 


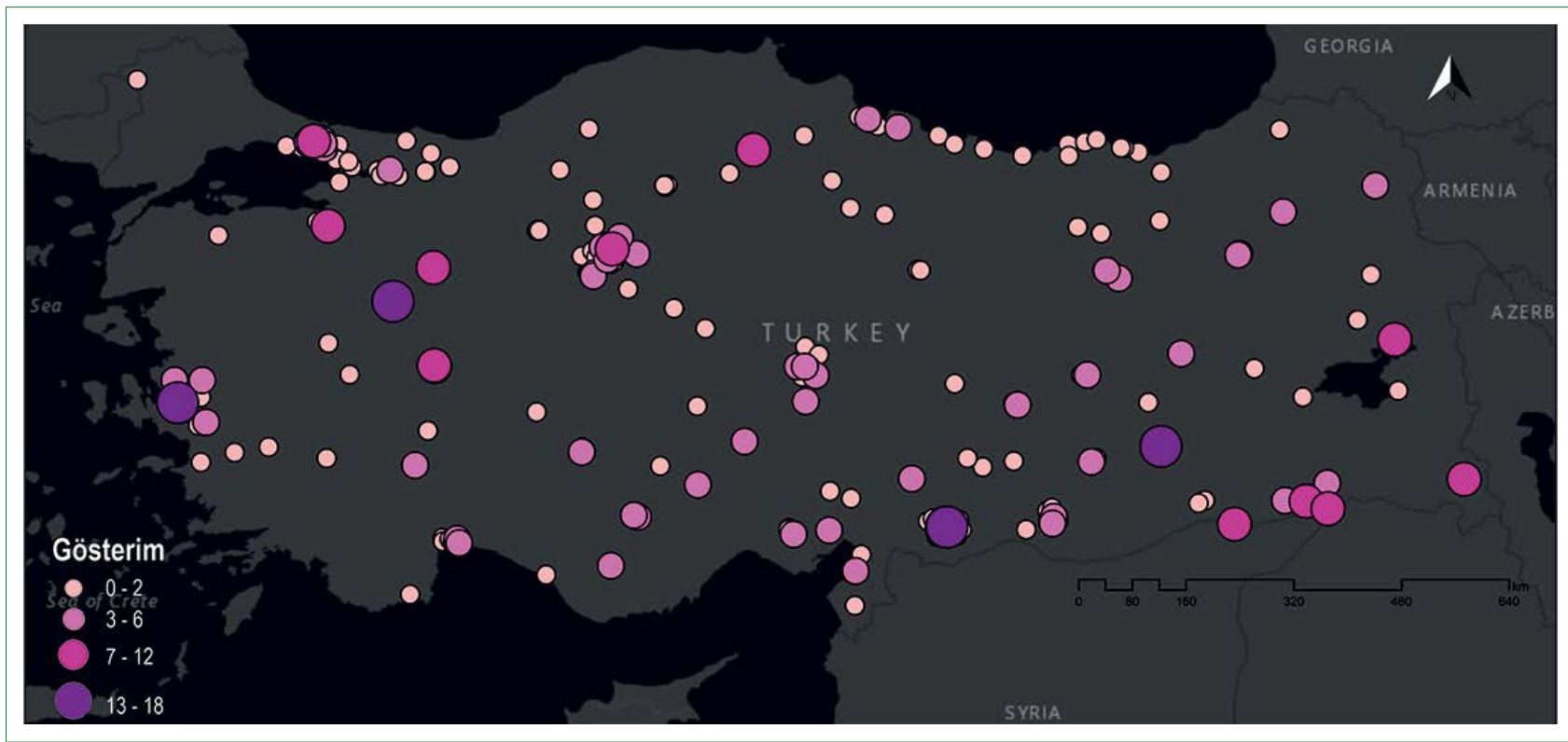

Şekil 8. Uygulamaların kapsadıkları mahalle sayılarıın illere göre dağıımı.

etkin bir yenileme sürecinin içerisine girmiştir. Yenilemeye odaklı bu ortam 2000'ler sonrasında ise, "kentsel dönüşüm" olarak adlandırılan uygulamalar ve bu uygulamalara yön veren bir mevzuat ile birlikte güçlenmiş ve Türkiye kentleşmesinin temel dinamiklerinden biri haline gelmiştir. Bu aşamadan itibaren yenileme uygulamaları noktasal ve parçalı biçimde gelişim gösterdiği ölçüde büyük alansal ve bölgesel operasyonlar biçiminde hayata geçerek önemli değişimler ortaya çıkarmışlardır.

2000 'lerle birlikte izlenen bu büyük değişimin sadece bir dönemsel yaklaşım olarak açıklanamayacak tarihsel açılımlarının bulunduğu açıktır. Bir başka ifade ile bugün karşımıza gelen büyük ölçekli kentsel müdahaleler, göç ve gecekondulaşma süreci ile başlamış kendine özgü kentleşme sürecinde farklı ölçek ve içeriklerde deneyimlenmiş yenileme uygulamalarının yaygınlaşmış bir hali olarak okunmalıdır. Bu kapsamda kabarık bir liste oluşturan mevzuat gelişiminin “yasak”lar üzerinden kurmaya çalıştığı dilin aslında emek süreçleri ve taşınmaz piyasası aracilığıyla sessiz bir anlaşma olduğunu söylemek yanlış olmayacaktır. Zira yasal düzenlemelerin içerik ve kurgusu, ülkesel düzeyde izlenen ekonomik, siyasal ve toplumsal gelişmelerin ve dolayısıyla temel kırıma noktalarının ortaya çıkardığı yeniden yapılanmalar biçimindedir.

Kentsel dönüşümü ilgilendiren tüm yasalar ele alındığında 2000 yılı öncesi bir "taviz" dönemi iken, 2000 yılı sonrası zaman dilimi bir "müdahale" dönemini içermektedir (Şekil I0). $2000^{\prime} l i$ yıllardan sonraki dönemin kentsel dönüşüm bakımından bir "müdahale" dönemi olarak ele alınmasının en önemli nedeni uygulamanın güçlü bir mevzuat ve TOKi gibi kurumların genişletilmiş yetkileri ile birlikte oldukça önemli bir ak-

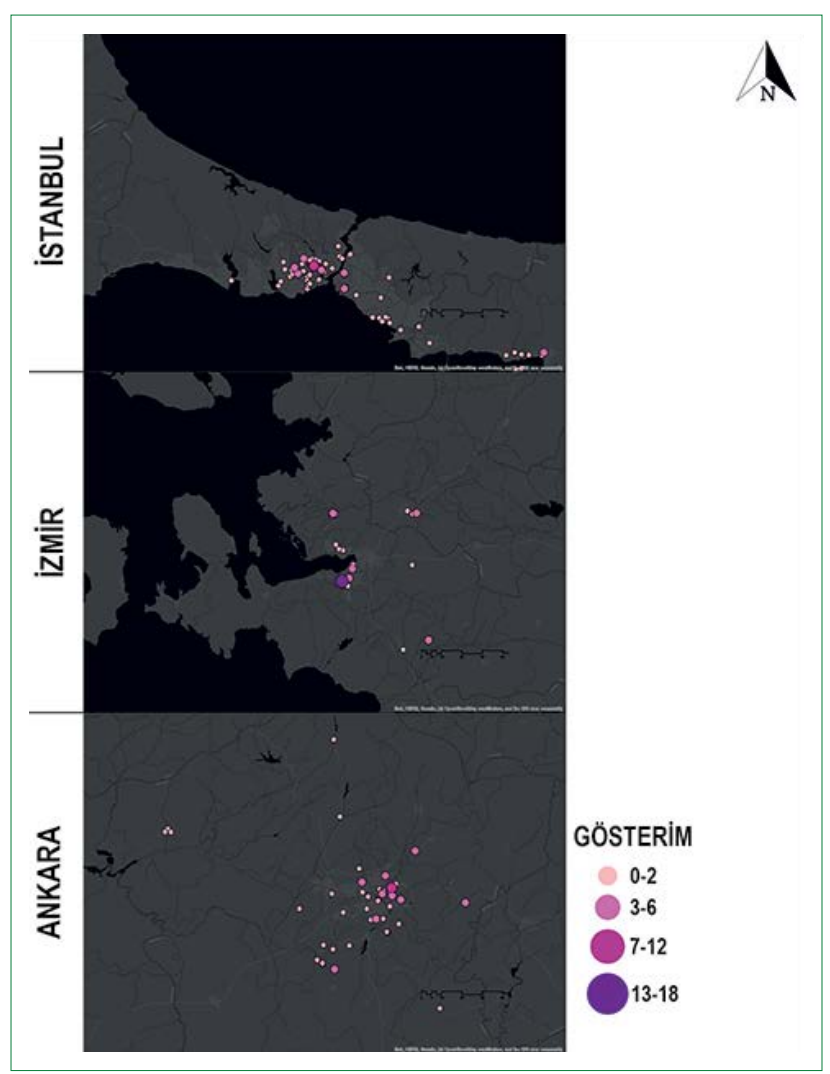

Şekil 9. Uygulamaların kapsadıkları mahalle sayısına göre dağıımının detaylı gösterimi.

tör olarak sürece dahil olmasından kaynaklanmaktadır. Buna bağlı olarak 2010 yılından itibaren ülkenin pek çok kentinde bir ya da birkaç mahalleyi içeren "kentsel dönüşüm projesi" ilanları çıkmaya başlamıştır. Uygulamaların ağırlıkla ilk ortaya 


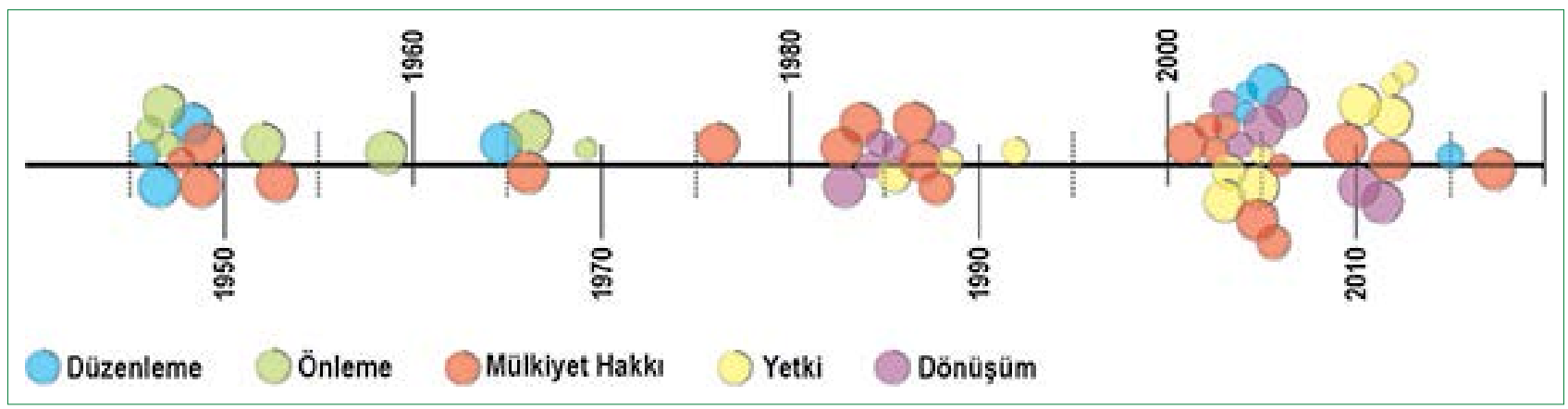

Şekil I0. Yasaların zamana göre dağıııı.

çıkma süreci açısından gecekondu alanı olarak nitelendirilebilecek bölgeleri konu alması, bu bölgelerin süreç içerisinde yasal statü kazanmış olsalar da sahip oldukları farklı toplumsal özellikler nedeniyle yapılan müdahaleleri daha da kritik hale getirmiştir. Projeler bu tür alanlarda yaşayan mahalle sakinlerinin kentle kurdukları sözsüz müzakereyi yeniden biçimleyerek, kentsel arsa üzerinden dağıtılacak rant temelinde bir pazarlık sürecine dönüştürmüştür.

Söz konusu projelerin büyük kitleleri etkiliyor oluşları, konunun temsiliyet ve haklar temelinde olması kent planlama disiplini içerisinde önemli bir tartışma alanı yaratmıştır. Neoliberal politikaların mekânsal izdüşümlerinin görünür olmaya başladığı dönemde hız kazanan projelerde müzakere süreçleri kent parçaları üzerine getirilen kararların uygulanmasında etkili bir araç olarak öne çıkmaya başlamıştır. Uygulayıcının karşısında yasal birer konut haline gelen gecekondular projelerin başlayabilmesi için gereken anlaşmalara imza atan taraflardan biri ve dolayısıyla, kentsel arsa üzerinden yaratılan ekonomik değerin bölüşümünde de söz sahibi aktörlerden biri haline gelmişlerdir.

Geniş kitleleri kapsayan projelere ilgi, doğalgaz gibi yeni kentsel hizmetlerden faydalanama, konut standartlarını yükseltme ya da sadece bir kentli gibi bir apartman dairesinde oturma ideali çerçevesinde artarken, kentsel dönüşüm bu tür mahalleler için adeta kendilerine dokunmasını bekledikleri bir sihirli değnek haline gelmiştir. Artık mahalle sakinleri içinde bulunduğumuz aşamada böylesi bir müdahalede kendi çıkarlarını maksimize edecek kararların üretilmesinde mülkiyet hakkını önemli bir araç olarak kullanacak şartlara sahiptir. Bununla birlikte, kentsel dönüşüm projelerinin avantajlarından yararlanma hakkını elinde tutamayan geniş kesimlerin varlığı da söz konusudur ve bu da projelerin neden olduğu/ olabileceği sosyal sorunlar nedeniyle en çok eleştiri alan yönünü oluşturmaktadır. Uygulamaların yukarıda ortaya konan tespitlerdeki şekliyle ülke genelinde yaygınlık kazanmış olduğu dikkate alındığında, kentlerde yaratılmış olan fiziksel etki ile birlikte sosyal değişim ve dönüşümün de belirgin hale gelmiş olduğunu söylemek yanlış olmayacaktır. Bu çerçevede kentlere yeniden biçim veren uygulamaların sözkonusu tarih- sel olarak göç ve gecekondu alanları üzerinde izlenir durumda olan sınıfsal ayrışma deseninde de farklılaşmalar yaratmış olduğu ve kentleri adeta harmanlayarak yeniden kuran böyle bir müdahale ölçeği içerisinde bu etkinin farklı araştırmaların konusu haline getirilmesi gerektiği açıktır. 


\section{KAYNAKLAR}

Afet Riski Altındaki Alanların Dönüștürülmesi Hakkında Kanun (2012, 16 May1s). Resmi Gazete. https://www.mevzuat.gov.tr/Metin.Aspx?Mevzu atKod=7.5.16849\&MevzuatIliski=0\&sourceXmlSearch $=$.

Anadolu Ajanı [AA]. (2008). İște Türkiye'nin Göç Haritası. https://www.haberturk.com/yasam/haber/81083-iste-turkiyenin-goc-haritasi.

Aydınlı, H.İ., Kaya, A. (2013). Yargı Kararları Örnekleri İle Türkiyede Kentsel Dönüşüm Uygulamalarının Sorun Alanları. Afyon Kocatepe Üniversitesi, İ̈BF Dergisi, 15 (2), 449-468.

Bektaş, Y. (2014). Bir Kentleşme Stratejisi Olarak Yasanın Kentsel Mekanı Dönüştürmedeki Etkisi: Ankara Örneği. Planlama, 24 (3), 157-172.

Belediye Kanunu. (2005, 3 Temmuz). Resmi Gazete. https://www.mevzuat. gov.tr/MevzuatMetin/1.5.5393.pdf.

Daşkıran, F., Ak, D. (2015). 6306 Sayllı Kanun Kapsamında Kentsel Dönüşüm. Yönetim ve Ekonomi Araştırmaları Dergisi, 13 (3), 264-288.

Demirkol, S., Bereket Baș, Z. (2013). Kentsel Dönüşümün, 6306 Sayılı Yasa Kapsamında Hak Ve Özgürlükler Açısından Ele Alınması. TBB Dergisi, $108,23-70$

Erman, T. (2010).“Kent ve Gecekondu”, Türkiye Perspektifinden Kent Sosyolojisi Çalışmalar. İstanbul: Örgün Yayınevi.

Genç, F.N. (2014). Gecekonduyla Mücadeleden Kentsel Dönüşüme Türkiye'de Kentleşme Politikaları. Adnan Menderes Üniversitesi Sosyal Bilimler Enstitüsü Dergisi, 1 (1), 15-30.

Görün, M., Kara, M. (2008). Kentsel Donuşum Projelerinin Hukuki Alt Yapısı Ve Sosyal Sorumluluk Çerçevesinde Belediyelerin Rolü. Yönetim Bilimleri Dergisi, 6 (1), 30-39.

Gürcanl, G.E., Yönez, E., Yönez, E. (2017). 6306 Sayılı Kanuna Göre Riskli Bir Binanın Dönüşüm Süreci ve Karşılaşılan Sorunlar: Bir İlçe Belediyesi Örneği. http://www.imo.org.tr/resimler/ekutuphane/ pdf/18214_20_52.pdf.

Güzey, Ö. (2012). Türkiyéde Kentsel Dönüşüm Uygulamaları: Neo-Liberal Kent Politikaları, Yeni Kentsel Aktörler Ve Gecekondu Alanları. İdealkent, 7, 64-83.

Karasu, M.A. (2009). Devletin Değişim Sürecinde Belediyelerin Konut Politikalarında Farklılaşan Rolü. Süleyman Demirel Üniversitesi İktisadi ve İdari Bilimler Fakültesi Dergisi, 14 (3), 245-264.

Kaya, E. (2009). Kentsel Dönüşüm Projeleri ve Halk Katılımı. Toplum ve Demokrasi, 3(6-7), 203-216.

Kurtuluş, H. (2010). Kent Sosyolojisinde Değişen Kavrayışlar ve Türkiyénin Kentleşme Deneyimi. Örgen Uğurlu, Nihal Şirin Pınarcıoğlu, Ayșegül Kanbak ve Makbule Şiriner (Ed.), Türkiye Perspektifinden Kent Sosyolojisi Çalışmaları içinde (s. 177-226). İstanbul: Örgün Yayınevi.

Öngören, G. (2013). Kentsel Dönüşüm Hukuku. İstanbul: Öngören Hukuk Yayınları Yayın No: 5.

Özden, P.P., Kubat, A.S. (2003). Türkiyéde Şehir Yenilemenin Uygulanabilirliği Üzerine Düşünceler. İTÜdergisi/A Mimarlık, Planlama, Tasarım, $2(1), 77-88$.

Özkaya Özlüer, I. (2018). İmar Barısıı Düzenlemesine Hukuki Bir Yaklașım. İnönü Üniversitesi Hukuk Fakültesi Dergisi -İnÜHFD, 9 (2), 313-340.

Şenyapilı, T. (2016). “Baraka”dan Gecekondu’ya, Ankara'da Kentsel Mekanın Dönüșümü 1923-1960. İstanbul: İletişim Yayınları.

Şimşek, S. (2016). Türkiyéde Kentsel Dönüşüm Uygulamaları. Ankara: Seçkin yayıncilik.

T.C. İçişleri Bakanlığ Afet ve Acil Durum Yönetimi Başkanlığ1 [AFAD] (2019). Türkiye Deprem Tehlike Haritaları İnteraktif Web Uygulaması. https://tdth.afad.gov.tr/TDTH/main.xhtml.

Tezcan, S. (2020). Göçle Oluşmuş Yaşama Bölgelerine Yönelik Dönüşüm Projelerinde Müzakereler (Doktora Tezi). İzmir: Dokuz Eylül Üniversitesi.

Tezcan, S. ve Zengin Çelik, H. (2017). İzmir Büyükşehir Belediyesi Tarafından Uygulanan Kentsel Dönüşüm Projeleri Üzerine Bir İnceleme. Mah- mut Güler ve A. Menaf Turan (Ed.), Belediyelerin Geleceği ve Yeni Yaklaşımlar III. Cilt içinde (s. 72-95). İstanbul: Marmara Belediyeler Birliği Kültür Yayınları.

Türkiye Planlama Okulları Birliği [TUPOB]. (2010). 5393 Sayılı Belediye Kanununun 73. Maddesinde Değişiklik Yapılmasına Dair 5998 Sayılı Kanuna İlişkin TUPOB Görüșü. http://www.spo,org.tr/tupob/detay. php?kod $=2235 \&$ tipi $=56 \&$ sube $=0$.

Zengin Çelik, H. ve Çilingir, T. (2017). Parsel Bazındaki Dönüşüm Uygulamalarının Kentsel Maliyetleri, Karşıyaka - Bostanlı Mahallesi Örneği. Planlama, 27(3), 329-346. 